\title{
37
}

\section{TRANSFORMING HUMAN SOCIETY FROM ANTHROPOCENTRISM TO ECOCENTRISM}

\section{Can We Make It Happen in Time?}

\section{BOB DOUGLAS}

\section{Abstract}

The publication of Tony McMichael's Planetary Overload in 1993 crystallised the emerging nature of the human predicament and the urgent need for a shift in the behaviour of our species. McMichael wrote, 'It is just now becoming conceivable that within several generations the human species may face threats to its survival because of its disruption of Earth's life supporting ecosystems.' Since then, human actions have resulted in the crossing of a number of critical system boundaries on which continuing human life on the planet depends. The survival of our species now demands transformative change in the way we relate to and care for the ecosystems on which survival and well-being depend. Global understanding of these matters has improved, while planetary overload has steadily worsened. We are going backwards, heading into eco-catastrophe, and we have succumbed to the psychological defence of denial. A change in the human mindset and in governance of the human economy will be needed to rescue us. We must now invest renewed efforts into the education of our young on the issue of ecocentrism and sustainability.

\section{Introduction}

Through more than 30 years of close professional association, Tony McMichael inspired a generation of epidemiologists and environmentalists. I argue in this paper that through his work, and others of his extraordinary ilk, we now 
know enough about what is threatening human futures to embark on a social engineering effort to change the human mindset in close collaboration with the up and coming generation, and especially schoolchildren.

In 1968, the ecologist Paul Ehrlich ${ }^{1}$ published The Population Bomb (Ehrlich, 1968), in which he expressed grave doubts about the world's ability to feed itself in view of the massive growth in the human population that was under way. It was Ehrlich and Holdren (1971) who popularised the I = PAT equation, which proposed that the impact (I) of a population on the world's environment was a function of population size (P), its affluence (A) and its technological sophistication $(\mathrm{T})$.

Then, in 1972, The Club of Rome published The Limits to Growth (Meadows et al., 1972), which suggested that continued human population growth and resource use could lead to the collapse of human civilisation during the 21 st century. Like Tony McMichael, I was appalled at the conclusions of both Paul Ehrlich and The Club of Rome when I read them in the early 1970s. But, unlike Tony, I failed at the time to understand the environmental nature of the evolving crisis. I do claim credit, however, for recruiting Tony to the Foundation Chair of Occupational and Environmental Health at the University of Adelaide, and it was from that position that he published his seminal work, Planetary Overload (McMichael, 1993).

He said there: 'Our burgeoning numbers, technology and consumption are overloading Earth's capacity to absorb, replenish and repair. These global environmental problems pose health risks, not just from localised pollution but from damaged life-support systems ... We cannot live apart from nature, remote from a great web of life ... The risk arises from the disruption of natural systems because we are exceeding the biosphere's carrying capacity - that is, we are overloading the planet's metabolic capacity.'

Planetary Overload makes it clear that humans cannot live apart from an intact natural web of life. Since its publication, McMichael also drove home the point, and mobilised the evidence, that climate change was a huge threat to human health and well-being (McMichael et al., 1996). This is a message thoroughly crafted for the ears of his anthropocentric hearers. For we live in an age of blatant anthropocentricism. Humans generally believe that we are at the apex of the evolutionary pyramid and that Earth has been created for us to exploit. But, as Tony pointed out in the introduction to Planetary Overload, 'Humans are newcomers to our planet with no special immunity against the usual fate of biological species on Earth; namely extinctions.'

1 Ehrlich later regretted that his wife, Anne, was not listed as co-author. 


\section{Boundaries of Sustainability}

In 2009, a group of senior Earth system and environmental scientists proposed a framework of planetary boundaries that were selected to define a safe operating space for humanity. The group asserted that, once human activity had passed certain thresholds or tipping points, which they called planetary boundaries, there was a risk of irreversible and abrupt planetary change. They pointed to nine Earth system processes which had boundaries that they considered to mark the safe zone for the planet. They argued that, because of human activities, three of these dangerous boundaries, especially climate change, biodiversity loss and biogeochemical flows, might have already been crossed, while others were in imminent danger of being crossed (Rockström et al., 2009). This work was updated in 2015 (Steffen et al., 2015).

\section{Anthropocentrism is the Problem}

I suggest that our anthropocentric mindset is the central problem, which we must address urgently. To do so will require a revolution in global thinking. We need somehow to build into the new mindset an understanding and response to the verities, which Tony spelled out in his book and which can be summarised by the term 'ecocentrism'. Humanity is currently hurtling down the anthropocentric highway towards a brick wall of total impossibility. Already, the signs that we are moving beyond the constraints imposed by physics, chemistry and biology are screaming at us on the billboards on the sides of the highway, but we ignore them. We are approaching a fork in the road, with a little sign that points down a bumpy track labelled 'ecocentric survival', but much of the traffic is travelling too fast to even notice the sign or the fork in the road.

We need to engineer a transition from the current, nearly universal human mindset, which sees humans as the superior species in total control of our planet, to a new operating paradigm where we recognise our utter dependence on healthy ecosystems and make their nurture central to our culture. Ecocentrism places welfare at the heart of the human social, psychological and economic enterprise. It understands the world as a collaborating system of networks, ecologies and relationships. It recognises that human systems are a subset of nature's systems and will survive only if they survive. A communal mindset shift of this kind will have profound consequences and will lead to changes in the way we live, govern ourselves and structure the global economy. 


\section{Mindset Shifts}

I am talking here of a very large social engineering project. We must recognise that this shift in the communal mindset will need to have a number of dimensions - cognitive, ethical and spiritual - and it must also be practical in its operation and applications. Mindset change of this kind is unlikely to follow from promotion of fear and doom saying. It is more likely if people see in the new vision of an ecocentric future, the promise of a better and more fulfilling life. And, it is more likely where there is grass-roots involvement and people have a sense of empowerment about the changes that they will help to bring about. Mindset change will not come from a pulpit or a classroom teacher, but from one-on-one engagement among people of all ages who respect each other.

Malcolm Gladwell (2000) has drawn attention to the fact that shifts in the communal mindset and behaviour can occur quite rapidly when less than 20 per cent of the population decides, for whatever reason, to make the shift. Communal mindset changes occur frequently, and sometimes quite quickly. Cataclysmic events, like the attack on Pearl Harbour and the Great Depression (Gilding, 2011), can rapidly induce a shift in communal thinking. The Arab Spring is a recent example of a profound communal shift in mindset and action that followed the suicide by immolation of a street vendor in Tunisia (Anon., 2012).

Of course, we cannot predict the nature, timing or magnitude of unpleasant and cataclysmic events that could help to precipitate the shift. But, it is now very likely that such events will not be too far in the future. What we can do now is prepare the ground in modern society with new narratives about the benefits of a different mindset.

The Transform Australia Manifesto ${ }^{2}$ outlines a vision for Australia where the well-being of both humans and the health of the planet are synonymous; where we accept that nature is our provider and we are its stewards; where we acknowledge that our economy, ecology and ecosystems are interdependent; and where a sustainable future for our descendants is therefore possible. Transform Australia is not a coherent organisation but a network of individuals who have come together in various conferences and small groups in the past three years to discuss the conditions needed for a viable future.

2 On Facebook see: www.facebook.com/pages/Transform-Australia/192700014096588, accessed 10 April 2015. 


\section{Collaboration, Partnering and Compassion}

An essential feature of a new ecocentric mindset will be a new emphasis on collaboration and partnering and a de-emphasis on competition as a driver of our culture. The Transform Australia group has drawn heavily on the writings of Riane Eisler, whose book, The Real Wealth of Nations (Eisler, 2007), points to many examples in history, economics, sociology and biology that demonstrate the social, psychological and economic benefits of collaboration, both among humans and between humans and the planet. Our current economic model is driven by competition and barely values partnership, sharing and collaboration. It also fails utterly to value properly our environmental assets. Eisler identifies convincing Scandinavian and corporate examples where human well-being and economics have prospered as a result of economically valuing partnerism and collaboration. She and David Korten (Korten, 2010) have also drawn attention to the evidence from neurobiology of the stimulation of brain pleasure centres by collaborative and altruistic behaviour.

Another development relevant to this desirable mindset shift is an International Charter for Compassion (Armstrong, 2011), which has come together under the leadership of Karen Armstrong, a leading theological writer, who, in 2008, brought together representatives from Christianity, Buddhism, Hinduism, Confucianism, Judaism and Islam. The charter builds on the fact that the golden rule - doing to others what you would like them to do to you - is a common thread across these six great religions. The charter argues that humans urgently need to make compassion a clear, luminous and dynamic force in our polarised human world, and that it should be rooted in a principled determination to transcend selfishness. Compassion, it says, can break down political, dogmatic, ideological and religious boundaries. It will be born out of our interdependence and will be an enriching component of human relationships in a more fulfilled humanity. The charter concludes that compassion is indispensable to the creation of a just economy and peaceful global community. It complements Riane Eisler's view of partnerism and should be included in the essential re-engineering of human economics and governance.

\section{The Economy}

Tony McMichael had a great deal to say about economics in Planetary Overload. Much of what he said there continues to be true today. Ecological economics has evolved somewhat in the 21 years since his book appeared, but it is still far from mainstream. Our Australian economy, depending for its health on consumptionled growth in the gross domestic product (GDP), is insanely unfit for purpose. 
Nobody doubts the benefits that have flowed to global society from economic growth in the past, but consumption-driven economic growth is no longer a viable option for countries like ours (Quaker Institute for the Future, 2012). Nor can we continue to ignore the obscene inequity between and within human populations, which is increasing under the operation of the current economic model (Wilkinson and Pickett, 2009). Designing a new steady state economy that values our ecosystems, shares wealth more equitably and promotes partnerism and compassion at the expense of competition and domination is theoretically feasible. But, implementing such a change will require new approaches to human governance that respect the relationship between human communities and their ecosystems, strengthen the nature of community and operate on newly enunciated democratic principles of subsidiarity. None of this will occur while anthropocentricism dominates our individual thinking and our collective mindset.

\section{Governance}

In Planetary Overload, on page 335, Tony wrote, 'The embryonic conventions emerging from the 1992 Earth Summit may yet foreshadow a new global environmental consciousness. Without such an international commitment it is hard to see how we humans, living in an increasingly overloaded world can make the necessary transition in awareness, values and collective rational action.' Quite so! Rio+20 (Rio plus 20 conference, 2012) demonstrated convincingly that this hope is as yet completely unrealised. We are still behaving as though individual human and national interests are all that count. The penny has not yet dropped that human survival depends on the health of the planet and that, until we bring our formidable intellects to this challenge, we will be wasting precious time on trivia. In the 2012 Australian Capital Territory (ACT) election, there was clear division between contending parties about their attitudes to the environment, but so anthropocentric is our collective mindset that neither side dared to draw attention to the obvious difference. Three of four Greens lost their seats, although it had been their initiative that had placed the ACT in a remarkably strong position with respect to carbon emissions targets. Similarly, Greens are being marginalised nationally, and the recent US presidential election stayed well away from issues like climate change. It is not yet clear what form future ecocentric governance will take. But, it is definitely clear that Australian democracy in its present form will not do the job. It is too susceptible to the interests of those who fund political campaigns and to the influence of advertising and the media. In these circumstances, public and environmental good takes second place to those of special interests. 


\section{A New Human Narrative}

In the closing paragraph of Planetary Overload, Tony wrote as follows. 'Human history can be viewed as a succession of cultural and technological developments, enabling us to sidestep the natural ecological constraints on basic human biology.' And, finally, he wrote, 'we now depend on that same cultural ingenuity to find - soon - a path towards an ecologically sustainable, health supporting way of life.'

The vision for a new approach needs to be underpinned by a new cultural narrative that spells out the attractiveness of an ecocentric lifestyle. Developing the impetus for the new narrative requires fresh minds and new talents that will take us beyond a tired, self-centered, consumptive approach and will help us to rediscover the vitality of being an integral part of an evolving universe.

\section{Empowering Youth}

A transformation in mindset will not come about from the top down. But, I think it could follow from a determined empowerment of young people. They are less invested in and constrained than older generations by the operation of the current system and can build a new vision of a future for humanity that is both fulfilling and exciting, one to which they can actively contribute.

In Canberra, SEE-Change (www.see-change.org.au), a grass-roots, nongovernmental organisation, worked with the ACT Education Department and Catholic and Independent schools and colleges on a project aimed at engaging all of the 67,000 ACT school and college students on what we have described as '2020 Vision' (www.see-change.org.au/?q=node/369). New national curriculum guidelines now obligate schools across the nation to introduce a sustainability theme across subjects for all age groups. Canberra's Centenary year was celebrated in 2013. We invited schools to use this occasion to look forward rather than backward. Curriculum materials have been developed to focus on how Canberra could change in the lead-up to 2020, when our legislators are committed to achieve a 40 per cent reduction in carbon emissions, relative to 1990 levels, and an energy system that is 90 per cent based on renewable sources. We worked with educators and other community groups towards a Youth Parliament on Sustainability, held in November 2013, when elected representatives from 26 schools and colleges and from grades 4 to 12, met to debate recommendations from green papers prepared by senior students about Canberra in 2020. They agreed on 24 recommendations and elected a Cabinet that will now meet with the Planning Committee of the ACT Legislative Assembly to discuss their views. 
The Parliamentary White Paper that the Youth Parliament endorsed came about as a result of children across the education system, during 2013, considering the issues that now confront Canberra and our human world and applying their talents to planning for the world that they will inherit.

\section{Can It All Happen in Time?}

The concerns raised by McMichael in Planetary Overload were prophetic and are rapidly coming to pass. At a Canberra conference held recently, entitled 'The Future of Homo Sapiens' (Adams, 2012), Phillip Adams, in his keynote address, quoted the cellist Pablo Cassals, 'The situation is hopeless, we must take the next step.' I do not share the deep pessimism of many of the speakers at that symposium. Rather, I agree with Paul Gilding (2011) that 'humans are slow but not stupid', but that it will probably take a major disruption, which could come from a variety of sources, to move us towards the radical ecocentrism that will be required to avoid early extinction. In the meantime, I am heartened by evidence I see among young people's networks of their determination to find a better way forward. We need urgently to enable their building of the narrative that will shift the human mindset towards ecocentrism.

\section{References}

Adams, P. 2012. The Future of Homo Sapiens. Available at: manningclark.org. au/sites/default/files/mch_abstract_book-1.pdf, accessed 16 April 2014.

Anon. 2012. Street vendor Mohamed Bouazizi sets himself on fire - catalyst for Tunisian revolution/Arab Spring. Available at: slicethelife.com/2012/12/17/ street-vendor-mohamed-bouazizi-sets-himself-on-fire-catalyst-for-tunisianrevolution-arab-spring, accessed 13 February 2014.

Armstrong, K. 2011. Twelve Steps to a Compassionate Life. Random House, New York, USA.

Ehrlich, P.R. 1968. The Population Bomb. Sierra Club, San Francisco, California, USA.

Ehrlich, P.R. \& Holdren, J.P. 1971. Impact of population growth. Science $171,1212-7$.

Eisler, R. 2007. The Real Wealth of Nations: Creating a Caring Economics. BerrettKoehler Publishers, San Francisco, California, USA. 
Gilding, P. 2011. The Great Disruption: Why the Climate Crisis Will Bring on the End of Shopping and the Birth of a New World. Bloomsbury Press, London, UK.

Gladwell, M. 2000. The Tipping Point: How Little Things Can Make a Big Difference. Bloomsbury, London, UK.

Korten, D. 2010. Agenda for a New Economy; From Phantom Wealth to Real Wealth. Berrett-Koehler Publishers, San Francisco, California, USA.

McMichael, A.J. 1993. Planetary Overload. Global Environmental Change and the Health of the Human Species. Cambridge University Press, Cambridge, UK.

McMichael, A.J., Haines, A., Slooff, R. \& Kovats, S. (eds) 1996. Climate Change and Human Health. World Health Organization, Geneva, Switzerland.

Meadows, D., Meadows, D., Randers., J. \& Behrens, W. III. 1972. The Limits to Growth. Universe Books, New York, USA.

Quaker Institute for the Future 2012. Beyond the Growth Dilemma; Toward an Ecologically Integrated Economy. Available at: www.quakerinstitute.org/ wp-content/uploads/2012/10/BGD-web.pdf, accessed 16 April 2014.

Rio plus 20 conference. 2012. Available at: www.uncsd2012.org/content/documents/ 814UNCSD\%20REPORT\%20final\%20revs.pdf, accessed 16 April 2014.

Rockström, J., Steffen, W., Noone, K., Persson, Å., Chapin, F.S., Lambin, E.F., et al. 2009. A safe operating space for humanity. Nature 461, 472-5.

Steffen, W., Richardson, K., Rockström, J., Cornell, S.E., Fetzer, I., Bennett, E.M., et al 2015. Planetary boundaries: Guiding human development on a changing planet. Science 347, 736.

Wilkinson, R.G. \& Pickett, K. 2009. The Spirit Level: Why More Equal Societies Almost Always Do Better. Penguin, London, UK. 
This text is taken from Health of People, Places And Planet:

Reflections based on Tony McMichael's four decades of contribution to epidemiological understanding, edited by Colin D. Butler, Jane Dixon and Anthony G. Capon, published 2015 by ANU Press, The Australian National University, Canberra, Australia. 